
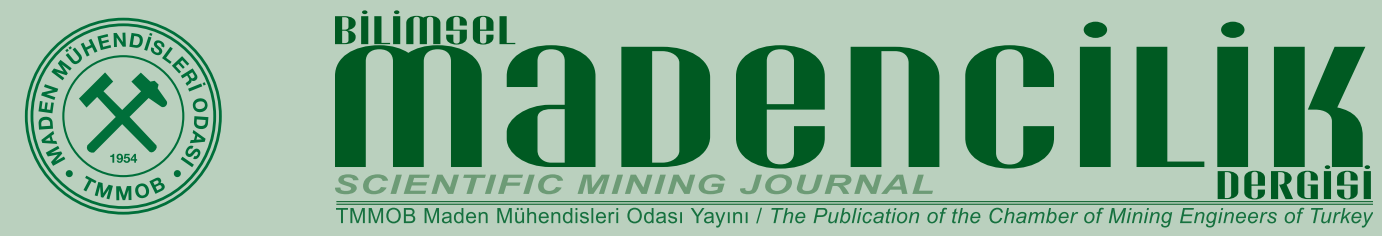

Derleme / Review

COAL BLENDING FOR THERMAL POWER STATIONS

TERMIKK SANTRALLAR IÇIN KÖMÜR HARMANLAMA

\title{
Mustafa Yörükoğlua,
}

${ }^{a}$ Mining Eng. MSc., ANKARA

Geliş Tarihi / Received

Kabul Tarihi / Accepted
25 Nisan / April 2017

19 Temmuz / July 2017

\section{Anahtar Sözcükler:}

Blending,

Stacking,

Reclaiming,

Stockyard equipment,
Quality management.

\section{ABSTRACT}

Coal blending which provide increase in efficiency, decrease in repair-maintenance costs and emission of harmful gases in coal fueled power plants, is in the interest of many countries both scientifically and practically. Nevertheless, there are many power plant operators in different countries showing no adequate interest to this important issue.

This paper briefly explains the importance of blending, types and methods of blending, total coal quality management and importance of stockyard equipment selection especially for mine-mouth power plants and points out that all these are essential parameters of a good blending.

\section{Öz}

Keywords:

Harmanlama,

Yığma,

Yığından alma,

Stok sahası ekipmanı,

Kalite yönetimi.
Kömürle çalışan santrallarda verim artışı, tamir bakım masraflarında ve zararlı gazların emisyonunda azalmayı sağlayan kömür harmanlama konusu bilimsel ve uygulamalı olarak birçok ülkede gerekli ilgiyi görmekle beraber, konuya yeterli ilgiyi göstermeyen farklı ülkelerde santral işletmecileri de bulunmaktadır.

Bu makale, özellikle yanındaki kömür ocağından yakıt sağlayan santrallar için bu konuya neden önem verilmesi gerektiğini, harmanlama yöntemlerini, toplam kömür kalite yönetimini, stok sahası ekipman seçiminin önemini kısaca belirtmekte ve tüm bu hususların iyi bir harmanlama için gerekli parametreler olduğuna işaret etmektedir. 


\section{INTRODUCTION}

Coal blending, on which scientific researches were intensified starting from 1980s, have been considerably improved both theoreticaly and practically. Particularly coal exporters and mine-mouth power plant operators supplying coal from one or different coal mines achieved desired quality coal by applying blending techniques.

Developments in blending were primarily observed in the coal producing/exporting countries (such as Australia, South Africa) and in coal importing countries (such as Netherland). In the process of time mine-mouth plant operators fed from one/several coal mines started efficient coal blending works.

Most mine-mouth power plant operators do not concentrate on blending, size and type of stockyard and its equipment and consequently the benefits that may come out. Stockyard equipments are generally perceived as a package system brought by the stockyard equipment vendors. Some technical parameters (such as, stacker/ reclaimer capacity, belt speed/capacity, etc.) are to be considered and detailed discussions with the vendors including size and type of stockyard before the construction and erection works, are to be fulfilled. Power plant operators should show interest on quality distribution in the coal mine, sequence of production, type and method of blending systems, total coal quality management system and its effects to boiler efficiency. These items are inseperable parts of the whole.

It is difficult to state that an adequate interest to this important issue has been shown by the plant operators in Turkey. There are some scientific studies (Ural and Onur, 1994; Taştekin, 2002; Erarslan et al., 2001; Ural, 2007) and practical approaches on this issue but the numbers of both should be increased.

\section{OBJECTIVES IN COAL BLENDING}

Coal quality in any coal seam shows spatial variability. It is impossible to have a uniform quality of coal if it is not processed after mining. Parameters determining the coal quality (Lower heating value, ash, moisture, volatile matter, grindability, sulphur, etc.) are so important that any excessive fluctuation in the quality may result in costs and environmental pollution in negative terms, even though calorific values of coal meets the demanded range of boiler. Nkuna (2009) points out that high ash content impedes the burning capability of boilers, causing low temperatures that lead to boiler trips. In short, coal quality fluctuation directly affects plant efficiency, availability, unwanted emissions and costs (Mahr,1988; KEMA, 2004; Sathyanathan, 2011).

Mineral matter composition in ash is also very important from point of slagging and fouling. Mineral matters directly affect mill life and repair-maintenance costs. However, non-additive properties of mineral matters during combustion are very complex and even if the blended coal meets the design coal spec, full scale tests for a certain time may be favourable for boiler efficiency before making a decision of blending system. Burning profiles of coals with different properties (such as high ash, low ash coals from the same mine or different mines) with certain percentages should be obtained before blending system decision.

Spontaneous combustion (sponcom) is directly related with coal quality and long time retention of coal in the stockyard. Carbon and oxygen are basic elements of sponcom while sulphur plays a triggering effect. Sulphur compounds in coal liberate considerable heat as they oxidize. If not taken under control, sponcom creates environmental pollution and causes loss of fuel (coal). Blending can be an important technical solution to prevent sponcom (Sathyanathan, 2011; Sloss, 2014). Coal retention period in the stockyard is so important that first in-first out rule can be applied when sponcom is concerned (McCartney, 2006).

When a favorably blended coal is fed to a dated boiler, plant efficiency could be increased by at least $4 \%$ (Sloss, 2014). This means a reduction in coal production, extending mine life, reduction in overburden material (in open pits), less slagging, reduction in repair-maintenance, less harmfull gas emission, etc. and consequently increase in profit and money saving.

The primary objective of blending is to maximize uniformity of a non-homogeneous coal so as to have a better efficiency of power plant, an environmentally friendly system, saved fuel cost and extended coal reserve life (Renner, 2013; Gupta and Boruah).

\section{TYPES AND METHODS OF COAL BLENDING}

Many scientific studies have been carried out to bring an optimum solution to blending issue. Studies include simulation techniques taking into consideration the coal geometry, coal quality parameters and mining system applied (Benndorf, 
2013), blending optimization under uncertainty (Shih and Frey, 1993) for expected costs of blending, coal blending optimization for coal preparation production process based on genetic algorithm (Xi-Jin, 2009), linear programming technique for optimum blending (Erarslan et al., 2001), and so many other techniques. Meanwhile manufacturers developed suitable machinery and equipment for coal blending. All these studies carried out and equipments manufactured are for the solution of specific needs, i.e. blending method and the machinery for any power plant are to be tailor made.

Blending starts with the coal mine. Number of coal seams, quality of each seam, quality distribution in the benches, sequence of production and all similar data will be very useful in blending operations. Best method to understand the quality distribution is 3D mapping of the whole coal field. Production planning also provides a very good idea before starting blending.

During mining operation coal is transported by belt conveyors (or by other means) to stockpiles, crushers (mills) and boilers. During blending of two/more coals having different qualities, if the weighted average of the parameters are regarded, it may result in unwanted results. Knowing the additive (blend value is the average value of the coals within the blend, e.g. lower heating value, moisture, volatile matter, etc.) and non-additive (blend value is not the average value of the coals within the blend, e.g. grindability, fusion temperature, etc.) features would be beneficial in order not to lead to unexpected surprises (KEMA, 2004; Arora and Banerjee; Sathyanatyan, 2011).

A power plant needs a continuous and homogeneous flow of coal which meets the desired design coal values (coal quality on which the boiler is designed) which are mainly lower heating value, ash content, moisture content and sulphur content. While feeding the coal to power plant, the parameters defining the coal quality change and fluctuations in the quality inevitably occur even in a very short period of time.

In order to determine the best type and method of blending the best approach is to carry out the tests in the power plant for a couple of days/weeks but not in pilot scales. Because the results of full scale tests are unquestionable.

\subsection{Types of Blending}

There are three types of blending to achieve a de- sired blend quality. The figures 1, 2 and 3 simplify the concept of blending types.

Mine contractor is to produce lowest and highest quality of coal (cut off value of coal) defined in the coal supply contract. However, the mine contractor is to supply the coal within range coal limits, otherwise pays penalty. Quality $a$ and $b$ are the lowest and highest values of any parameter of coal. Quality b1 and a1 are the range coal values on which the boiler is designed. Boiler shows a good efficiency when the coal quality supplied to the boiler is in this range. Design coal value $(\sigma)$ gives the best boiler efficiency.

\subsubsection{Mixing}

As the name indicates this is a way of mixing two or more types of coals having different qualities (e.g. low ash coal with high ash coal). Mixing never enables the operator to have a uniform coal pile and the mixed coal quality may fluctuate between the lowest and highest figures of the parameters (ash, LHV, etc.) if mixing is not done well enough (although the aim is to stay in range coal values). The figure 1 below shows the coal quality fluctuation that may happen while feeding to power plant.

\subsubsection{Blending}

It is a system harmonizing two or more different coals having different qualities with/without the same origin. Blending is completely different from mixing and it is aimed to stay in the range coal constraint of boiler. Range coal contraint covers mainly lower heating value, ash, moisture and sulphur. In practice, the constraint is exceded time to time because of incoordination and mismanagement (Figure 2).

\subsubsection{Homogenization}

Homogenization refers to a more consistent supply of coal quality fluctuation as much close as to design value of the boiler and it generally refers to same origin of coal. Additionally, besides the main parameters, it also aims to lessen the fluctuations of some mineral matters, e.g. $\mathrm{Ca}, \mathrm{Si}$, etc. which directly affect the mills, boilers and efficiency.

Homogenization requires a very good mine-stockyard-power plant management information and coordination system. Input quality to stockyard must not show big fluctuations (so, a very good production-quality planning is to be ensured) and 
the layers of coal piled onto each other should be thin enough (Figure 3).

\subsection{Methods of Blending}

Before making a decision about the method of blending some questions must be clarified (Mular et al., 2002):

a- How many different qualities of coal are to be stacked?

b- What are the mineral characteristics of each quality (Density, susceptibility to sponcom, stickness, grindability, ash composition, etc.)

\section{c- How much storage is required?}

d- What proportion of live to dead storage is required?

e- Is a FIFO (First in- first out) stacking and reclaim required?

f- Type and capacity of existing (if any) stacking/ reclaiming equipment and belt conveyors?

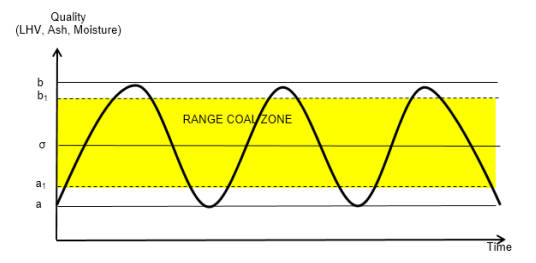

Legend:

a:Lowost value of any coal parameter
bi:tighest value of any coal parameter

11:Lowest vilue of any range coal paramoter
b1: Highest value of any range coal paramerts a: Design caal value

Figure 1. Coal quality may exceed b1 and a1 (Range coal) values in Mixing

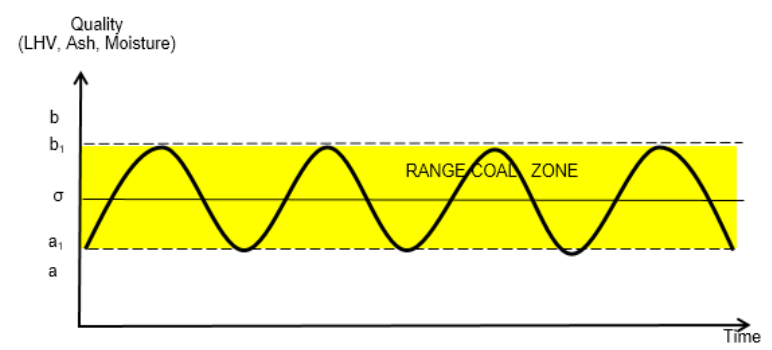

Figure 2. Coal quality values fluctuate in range coal quality limits of boiler in Blending

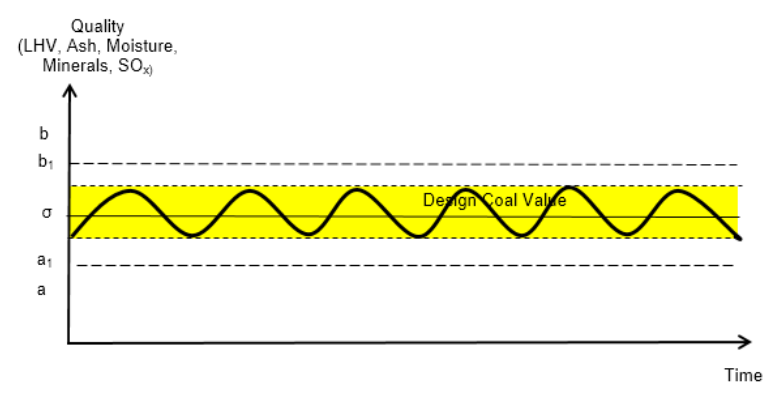

Figure 3. Coal quality values cosiderably close to design coal value of boiler in Homogenization

\subsubsection{Stacking}

The following explains the most widely used two methods of stacking, especially in the mine-mouth stockyards, i.e. Windrow and Chevron (Pavloudakis and Agioutantis, 2001). The others such as cone-shell, strata, chevcon, etc. are not given in this paper.

\subsubsection{Windrow Stacking}

This method has a principle of horizontal stacking, i.e. direction of movement of the boom is in parallel to the direction of the movement of the stacker.

Stacking starts when the boom is in the lowest position at the other edge of the stockyard, opposite to the stacker. After the completion of the first stacking of the first windrow (small pile) line, slewing angle of the stacker boom is changed to a new position and new stacking starts in opposite direction. As soon as the first level is completed the stacker boom is lifted to a new position and next windrow lines are stacked in the gaps of previous windrow lines. This way of stacking is carried on until the desired height of stockyard is completed (Figure 4 and 5, Photograph 1).

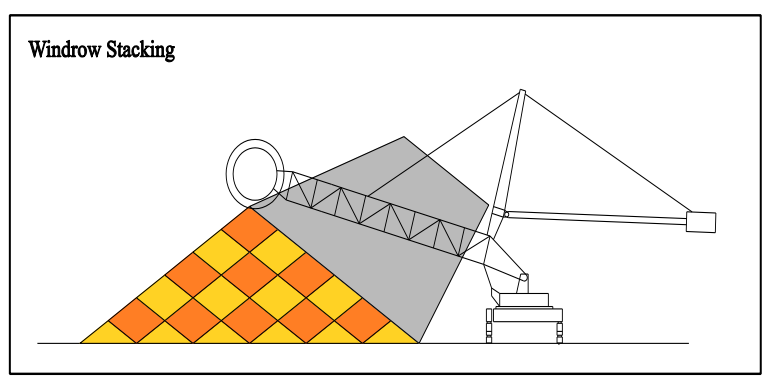

Figure 4. Windrow Stacking

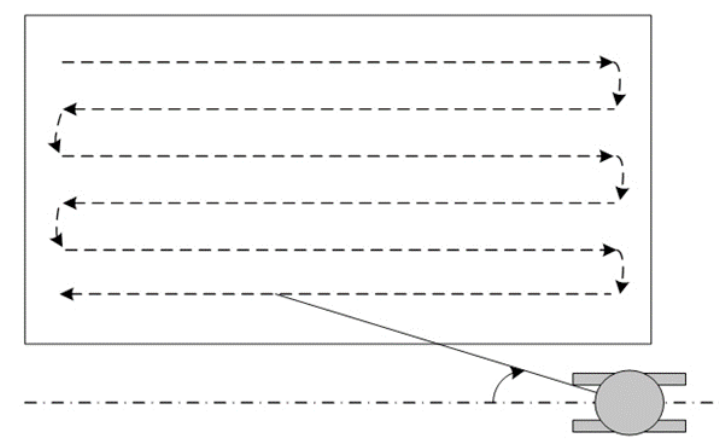

Figure 5. Boom movement when stacking first level in Windrow method (Joo and Woo, 2011) 


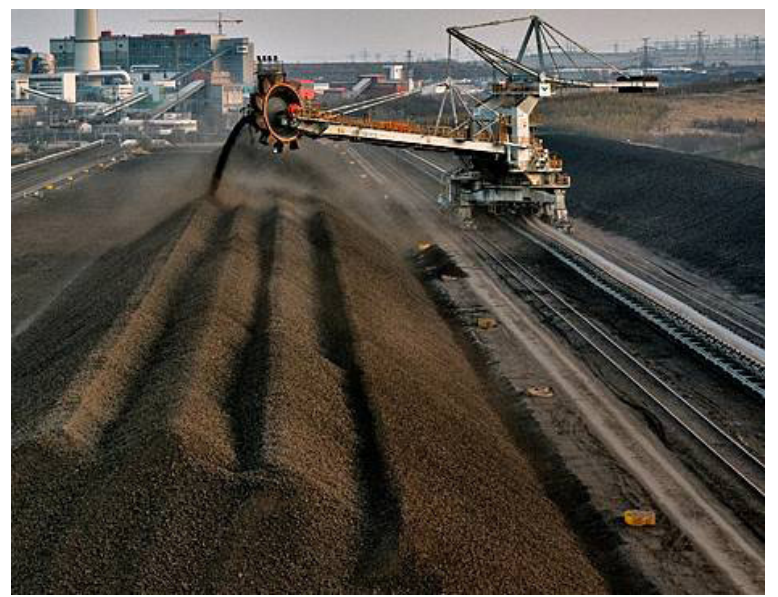

Photograph 1. A good example of Windrow Homogenization (Valenta, 2013)

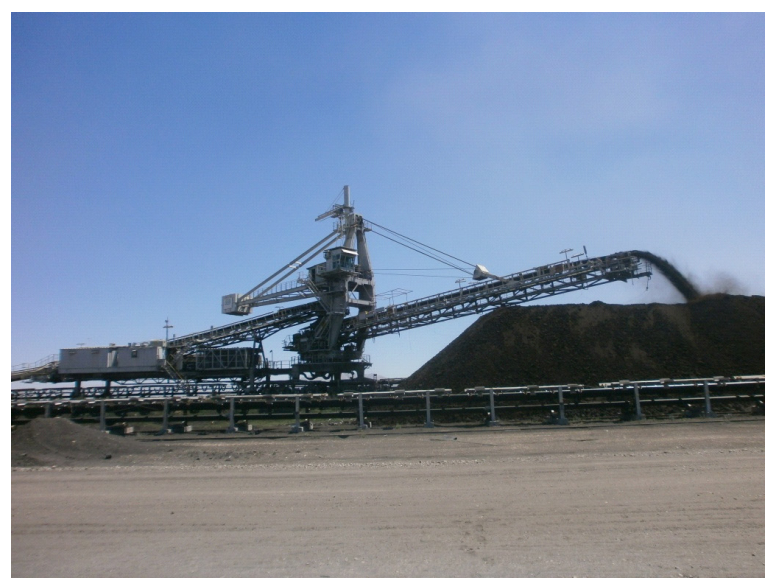

Photograph 2. Windrow stacking at Afşin-Elbistan Stockyard

\subsubsection{Chevron Stacking}

This method also requires a horizontal stacking principle, but in the form of big piles on top of each other. Stacking starts with the lowest position of the stacker boom and slewing angle is almost fixed to the center of the stockyard and the stacker moves along the stockyard or to a defined length of the stockyard. As soon as the defined length is achieved the stacker moves back and the boom is lifted upward to its new position to create a new layer and stacker starts piling up the coal on top of the previous layer. When the stacker moves back and forth, a cross section of triangular bands are developed. Thickness of each layer on top of previous one is to be thinner for a better blending. Each coal layer has a different quality (Figure 6).

Windrow is the principal method of stacking app- lied at Afşin-Elbistan stockyard at home (Photograph 2). The ideal lenth of piles were determined as 100 meters. Height and width of windrows are approximately $12 \mathrm{~m}$. and $23-27 \mathrm{~m}$. respectively (AEL, 2015).

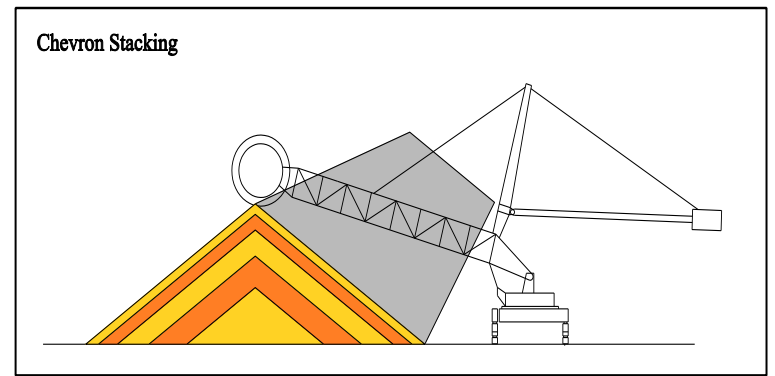

Figure 6. Chevron Stacking

\subsubsection{Reclaiming}

There are mainly three methods of reclaiming (Mühlbach, 2011; Van Horssen, 2013):

\section{-Long travel reclaiming}

-Bench/Block reclaiming

-Pilgrim step reclaiming

In long travel reclaiming method the reclaimer travels along the stockpile while cutting coal pile. Reclaimer boom height, depth and boom slewing angle are to be set to a position before reclaiming. At the end of the stockpile and before backward movement, reclaimer boom height, depth and slewing angle are changed to a new position. Boom slewing angle is not changed during movement.

In the bench reclaiming method, stockpile is reclaimed bench by bench to the end of the stockpile by changing the slewing angle of the boom during reclaiming. When the reclaimer arrives end of the stockpile, the reclaimer moves back to the starting point of the stockpile and lowers the boom for the second ( third, etc.) bench and moves forward again by changing the slewing angle to reclaim the second bench and so on. Pavloudakis and Agioutantis (2001) state that the most economical way to accomplish the bench reclaiming method is to use three benches.

The principle of block reclaiming is almost the same with bench reclaiming except that the reclaimer does not travel along the stockpile but to a certain predetermined distance. When the predetermined distance is reached the reclaimer moves back to the starting point of the stockpile and takes its new position as in the case of bench 
reclaiming method and this process continues till the reclaiming of all block having a predetermined length.

In both (bench and block) methods reclaimed part of the pile resemble a sickle shape because of the slewing angle of the boom. In order to supply a constant reclaim output, the slewing speed of the boom is to be controlled.

Pilgrim step reclaiming method resemble block method except the slewing movements and cuts are limited in number. After limited numbers of cuts the reclaimer moves back to the starting point of the pile and other bench is reclaimed.

Effective capacity ratio of each reclaiming method may considerably differ from each other. The combination of stacking- reclaiming methods and equipments is so important and they determine the effectivity of blending (Müller, 2010).

In general two single purpose machines (stackers, reclaimers) and multipurpose machine (stacker/reclaimer) are used for blending at home.

\section{COAL QUALITY MANAGEMENT SYSTEM, ANALYSIS, STOCKYARD EQUIPMENT}

Blending is not the unique instrument to supply optimum quality coal to power stations. There are lots of factors affecting this issue, such as sampling, equipment used at stockyard, coal quality management system including training of all staff, etc.

\subsection{On-line Analysis}

Blending processes generally rely on conventional sampling system. Analysis of coal samples require too much time and consequently blending works may not be in desired quality. Any delay in determining the quality of blended coal may create objectionable results in the mills and boilers, and gas emission limits may be exceeded.

Today many on-line analysers, in different trade marks, provide the plant operator carbon, oxygen, sulphur, moisture, low heating value and even the constituents of ash (Bhamidipati et al., 2004; Mahr, 1988). In practice on-line analysers indicate very high accuracy in determining those mentioned parameters when a good quality of coal (e.g., coal with low ash and moisture, high calorific value) is in question, however might show considerable discrepancies from the actual quality values when a bad/poor coal quality (e.g., coal with high ash and moisture) is concerned and it may result in contractual penalties. So, caution must be given to reliable number of samples from the mine, on-line analyser values, and comparison of actual quality values when low grade coals are to be blended.

\subsection{Stockyard Equipment-Size of Stockyard}

Depending upon the capacity of power plant, coal mine design and sustainability of production, coal quality, variation of quality in the coal field, sponcom feature of coal, available land size for stockyard, etc.; the size (buffering capacity) and type of stockyard (conventional longitudinal, circular) can be calculated and designed (Oberrisser, 2008; Ural, 2007). Thereafter the step is the selection of equipment type. Selection also depends on the type and method of blending.

Stacking equipment can be of rigid boom, luffing boom, slewing boom, retractable boom types or combination of these (Figure 7).

There are many types of reclaimers, such as bucket-whell, bridge, gantry, drum, portal, semi portal and drum. Each one may have different capacity depending on method of reclaiming, size of pile, etc.

A detailed discussion with the manufacturers (vendors) of stockyard equipment is of vital importance before making a final decision about the size and type of stockyard equipment. Cost and operational performance of equipment should also be considered. Before contract negotiations for the procurement of stockyard equipment, all types of information about the mine and coal, available land for stockyard, capacity of power station, grain size, crushers and mills, belt conveyors, ash handling system, etc. should be supplied to the manufacturer for the right choice of equipment because the stockyard equipment is to be tailor design equipment.

\subsection{Coal Quality Management System}

Blending, which is a phase in coal quality management system, starts in the coal mine. Management is to be aware of mine planning, production sequence, quality at the benches where the the production is currently carried out, method of stacking and reclaiming, quality of blended coal, $\mathrm{HGI}$ value of coal, efficiency of the boiler and emission figures.

A tight information coordination at each point of concern gives the management a good decision 

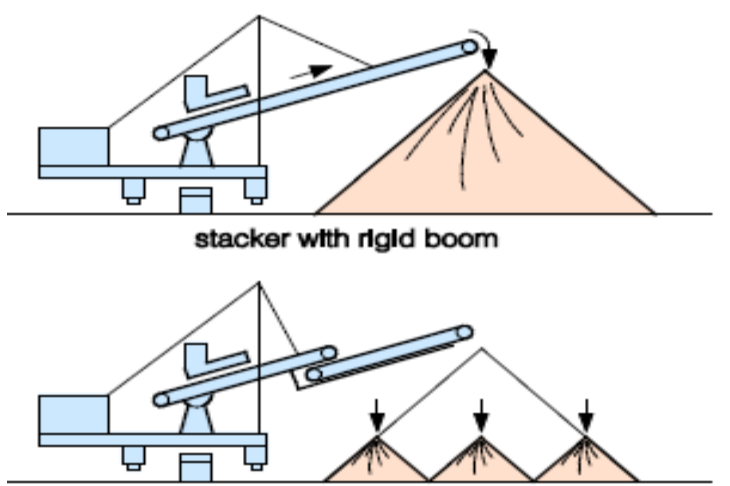

stacker with rigid and retractable boom

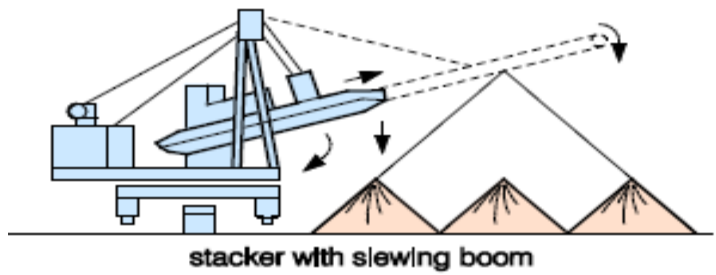

Figure 7. Coal Stacking Equipment (Sloss, 2014)

making capability for the best efficiency of the boiler. What is meant here is not only the coal management system, but total coal quality management system.

Such a management system requires rapid laboratory analyzers, monitoring equipment such as CCTV (Close circuit television) system, on-line analysers, sensors (belt weighers), GPS (For machine position), automatic coal samplers, PLC (Programmable Logic Controller) and very well trained stacker/reclaimer operators (Valenta, 2013). A control module for each phase and a general module are to be established for monitoring and control of all activities in detail.

\section{CONCLUSIONS}

Blending is an important issue on which many scientific studies and practical works have been carried. Emission of harmful gases as well as the considerable reduction of repair and maintenance costs of mills and boilers of power plants can be achieved by a proper blending method. Efficiency increase of boilers by a proper blending returns in big savings in monetary terms.

There are different types and methods of blending as well as different types of stockyard equipment. Optimum blending requires detailed investigation of the best method of blending together with the best suiting stockyard equipment. Type and size of stockyard, coal quality distribution in the mine

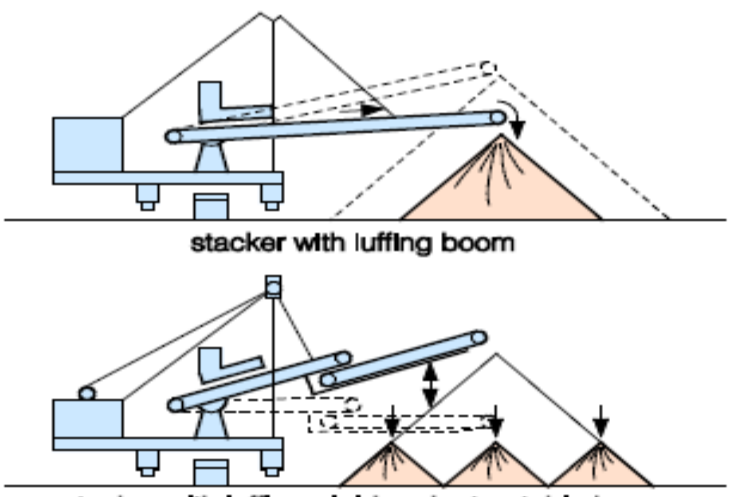

stacker with luffing, rigid and retractable boom

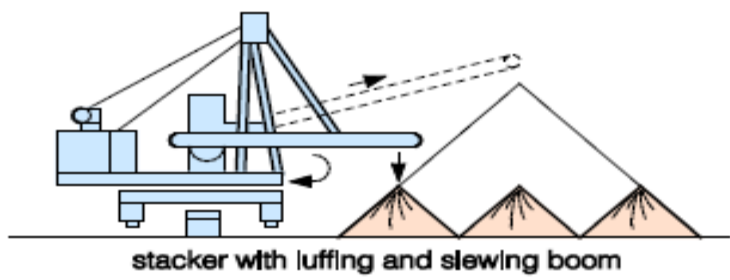

and sequence of production, coal quality analysis and similar parameters are integral part of a good blending. Detailed discussion of stockyard equipment with the vendors is a must. Total coal quality management system must be established for a sustainable supply of desired quality coal to the boiler.

Scientific studies and practical works on blending should be supported and/or carried out by coal fueled power plant operators in Turkey.

\section{REFERENCES}

AEL (Afşin -Elbistan Lignite Establishment), 2015. Stockyard Equipment and Operation Introductory Informative Booklet.

Arora, A.K., Banerjee, D., Optimization of Coal Blend Proportions for Sustained Improvements in Generation \& Efficiency. http://www.indianpowerstations.org/IPS\%20 2013\%20Presentations/Day-2\%20at\%20PMI\%20 NTPC \%20Noida\%20UP/Aurobindo/Session $\% 20$ $12 \% 20$ Coal $\% 20 \& \% 20$ Ash $\% 20$ Management/ Paper\%202\%200ptimization\%20of\%20Coal\%20 Blend $\% 20$ proportions $\% 20$ for $\% 20$ sustained $\% 20$ improvements $\% 20 \% 20$ in $\% 20$ generation $\% 20 \& \% 20$ efficiency.pdf

Benndorf, J., 2013. Application of Efficient Methods of Conditional Simulation for Optimising Coal Blending Strategies in Large Continuous Open Pit Operations. International Journal of Coal Geology, 141-153

Bhamidipati, V. N., 2004. Rose, C. D., Russell, J. M., Compliance Blending of PRB Coal at B. L. England 
Station Using Cross-Belt Analyzer. Int. On-Line Coal Analyzer Technical Conference.

Erarslan, K., Aykul, H., Akçakoca, H., Çetin, N., 2001. Optimum Blending of Coal by Linear Programming for the Power Plant at Seyitömer Coal Mine. $17^{\text {th }}$ International Mining Congress and Exhibition of Turkey, 719-722.

Gupta, S. K. and Boruah, B., Coal Blending Management System-A Case Study. Holtec Consulting Private Limited, India.

Joo, Y.C., Woo, S. J., 2011. Reclaiming/Stacking Methods. ABB Stockpile-Mining Solution Library (Automation).

KEMA, 2004. Coal Blending-Expertise and Services of KEMA. https://tr.scribd.com/document/238333586/ Netherlend-Coal-Blending.

Mahr, D., (ed)., 1988. Coal Quality Control: Fundamentals and Applications. Joint Power Generation Conference: Papers. American Society of Mechanical Engineers.

McCartney, R. H., 2006. Designing and Upgrading Plants to Blend Coal. Power Magazine, http://www. powermag.com/designing-and-upgrading-plants-toblend-coal/b.

Mular, A. L., Halbe, D. N., Barrat, D. J. (Ed.), 2002. Mineral Processing Plant Design, Practice and Control Proceedings. Volume 2, Society for Mining Metallurgy and Exploration Inc. (SME) 1454-1459.

Mühlbach, P., 2011. Optimized Coal Handling. World Coal Power Technology.

Müller, K. P., 2010. Stacking, Reclaiming and Blending Effects, Mechanical Technology. http://www. thyssenkrupp-materialshandling.co.za/Images/332 StackingReclaiming_MechanicalTechnology_ Novemberlssue_13122010.pdf.

Nkuna, S., 2009. Coal Blending and Process Redesign for a Steam Generation Plant. Faculty of Engineering, Built Environment and Information Technology, University of Pretoria.

Oberrisser, H., 2008. Plant Design: Trends in Coal Pile Design. Power Magazine. http://www.powermag.com/ plant-design-trends-in-coal-pile-design/.

Pavloudakis, F., Agioutantis, Z., 2001. Development of a Software Tool for the Prediction of Coal Blending Efficiency. 17th International Mining Congress and Exhibition of Turkey, 675-681

Renner, C., 2013. Sampling to Support Coal Blending, What is Needed for Precise Blending. SGS Mineral Services.

Sathyanathan, V.T., 2011. Blending of Coals in Power Stations. $3 p$ http://webcache.googleusercontent. com/search? q = cache:5o06yrMVccEJ:www. cethar.com/products_html/scbBlending $\%$
2520 of $\% 2520$ Coals $\% 2520$ in $\% 2520$ Power $\%$ 2520Stations. $d o c+\& c d=2 \& h l=t r \& c t=c l n k \& g l=t r$

Shih, J. S., Frey, H. C., 1993. Coal Blending Optimization Under Uncertainty. Proceedings of the Tenth Annual International Pittsburgh Coal Conference, University of Pittsburgh, 1110-1115.

Sloss, L.L., 2014. Blending of Coals to Meet Power Station Requirements. IEA Clean Coal Centre.

Taştekin, C., 2002. Kömüre Dayalı Termik Santrallerde Yakıt Homojenizasyonu. Madencilik Bülteni, 30-31.

Ural, S., 2007. Determining the Size of Linear Stockpile for the Afşin-Elbistan (B) Power Station (Turkey). Beykent Üniversitesi.

Ural, S., Onur A., 1994. Afşin Elbistan Termik Santralında Kömür Harmanlama Çalışmaları. Çukurova Üniversitesi Mühendislik Mimarlık Fakültesi 15. Yıl Sempozyumu, 411-421.

Van Horssen, K.C., 2013. Bucketwheel Stacker/ Reclaimers: An analysis of Stacking/Reclaiming Methods. Faculty Mechanical, Maritime and Materials Engineering, Delft University of Technology.

Valenta, V., 2013. Total Coal Quality Management Systems. Coal Market in India, New Delhi.

Xi-jin, G.,2009. Coal Blending Optimization of Coal Preparation Production Process based on improved GA. The 6th International Conference on Mining Science \& Technology, 654-660. 